\title{
Life cycle assessment of beef cattle production in two typical grassland systems of southern Brazil
}

\author{
Milene Dick ${ }^{\mathrm{a}, *}$, Marcelo Abreu da Silva ${ }^{\mathrm{b}}$, Homero Dewes ${ }^{\mathrm{a}, \mathrm{c}}$ \\ ${ }^{a}$ Center for Research in Agribusiness, CEPAN, UFRGS, Porto Alegre, Brazil \\ ${ }^{\mathrm{b}}$ Forage and Agrometeorology Department, Agronomy Faculty, UFRGS, Porto Alegre, Brazil \\ ${ }^{\mathrm{c}}$ Department of Biophysics, Biosciences Institute, UFRGS, Porto Alegre, Brazil
}

\section{A R T I C L E I N F O}

\section{Article history:}

Received 30 July 2013

Received in revised form

19 January 2014

Accepted 24 January 2014

Available online 5 February 2014

\section{Keywords:}

Enteric fermentation

Global warming

Impact categories

Native grassland

Sustainable development

Winter pasture

\begin{abstract}
A B S T R A C T
The importance of animal production in the overall context of human activity is undisputed and influences food supply, job security, income producing, as well as landscape and local ecosystems conservation. This relevance enhances the charges by society as the environmental impacts of various activities, especially in relation to ruminant production amid the current problems of climate changes. In this context, we analyzed the main environmental impacts of two typical beef cattle production systems from southern Brazil, namely the extensive system (ES) and the improved system (IS), and identified the components that have the greatest environmental impacts using the life cycle assessment method. The basis of the system construction was a cattle herd that originated from 100 weaned heifers, four weaned calves, and the progeny of these cattle during their productive life (12 years), and the land areas, external inputs, and other natural resources and technologies necessary to the operations. The functional unit was the production of $1 \mathrm{~kg}$ of live weight. The values of greenhouse gas emissions, land use, and freshwater depletion in the ES were higher compared with those values obtained for the IS (22.52 and $9.16 \mathrm{~kg} \mathrm{CO} 2$ equivalents; 234.78 and $21.03 \mathrm{~m}^{2} \mathrm{a}$; and 0.217 and $0.0949 \mathrm{~m}^{3}$, respectively). These variations were attributed to the permanence time of the animals in each system and to the quality and production of the pastures. The ES presented lower potential impacts than the IS on metal depletion and soil acidification ( 0.000519 and $0.0536 \mathrm{~kg}$ Fe equivalents; and 0.0028 and $0.0038 \mathrm{~kg} \mathrm{SO}_{2}$ equivalents, respectively) mainly due to the pasture improvement practices and the salt supply to the animals. Moreover, the values of freshwater eutrophication and fossil depletion were higher in the ES than in the IS $(0.00383$ and $0.00219 \mathrm{~kg}$ P equivalents and 0.0042 and $-0.1255 \mathrm{~kg}$ oil equivalents, respectively). While the pasture nutrient loss from runoff and leaching defined the values of eutrophication, the introduction of legumes compensates the use of fossil fuels. The diversity of the results provides a better understanding of the environmental impacts of different production systems and of regional singularities.
\end{abstract}

(c) 2014 Elsevier Ltd. All rights reserved.

\section{Introduction}

The recent environmental problems present negative consequences for humanity and have alerted different agents and sectors of society to the finiteness of natural resources. Although these consequences have been touted for a few centuries, these questions have only recently been assimilated as equally or more important

\footnotetext{
* Corresponding author. Universidade Federal do Rio Grande do Sul, Centro de Estudos e Pesquisas em Agronegócios (CEPAN), Av. Bento Gonçalves, 7712, Faculdade de Agronomia, $1^{\circ}$ andar, 91.540-000 Porto Alegre, RS, Brazil. Tel/fax: +55 51 33086586.

E-mail addresses: milenedick@yahoo.com.br, milenedick@hotmail.com (M. Dick), marceloabreudasilva@yahoo.com.br (M. Abreu da Silva), hdewes@ufrgs. br (H. Dewes).
}

than the economic performance of activities. Discussions on the sustainability of different human activities have been highlighted (Robèrt, 2000), especially with regard to beef cattle production and the impacts of this activity on plant-animal dynamics (Blanco et al., 2007; Medeiros et al., 2007; Pedroso et al., 2004; Santos et al., 2006) and to global warming, acidification, eutrophication, and resources use.

To select the most appropriate production practices, an analysis of the sustainability of the systems are necessary. Tools that can determine whether different activities have adequate sustainable development principles can facilitate this analysis. Production activities should be environmentally correct, socially just and economically viable (Robèrt, 2000). To evaluate production systems based on these principles, the life cycle assessment method (LCA) can be used, due to amplitude with respect to categories and 


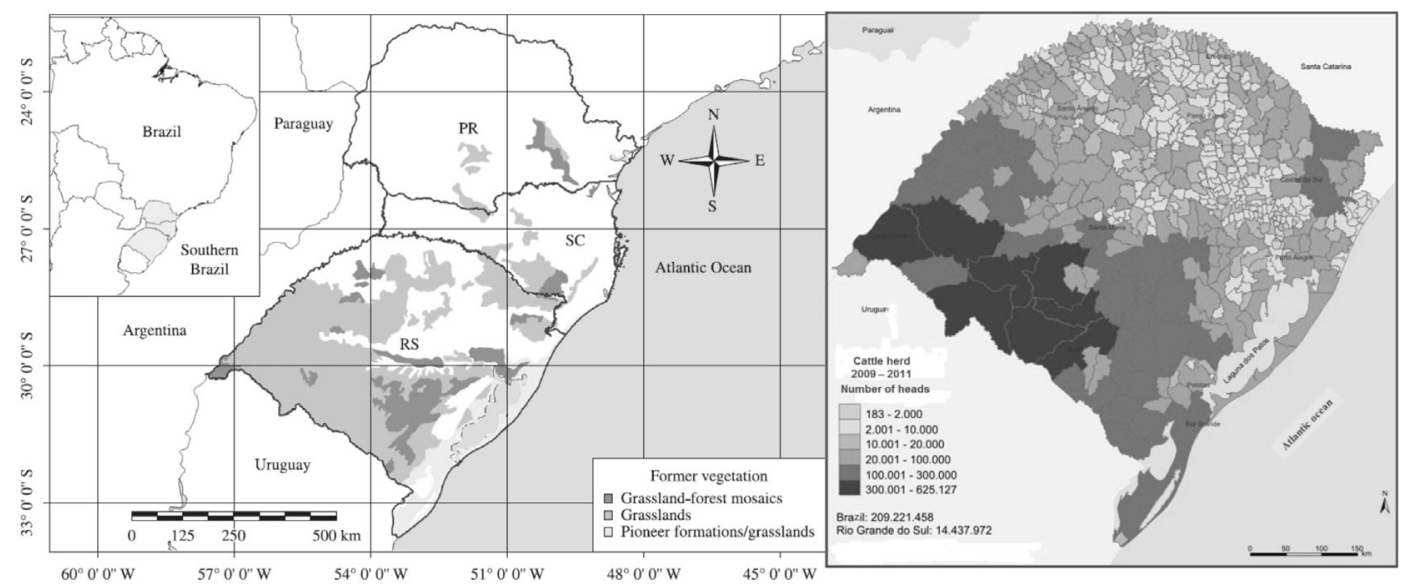

Fig. 1. Region characterized.

Source: Pillar et al. (2012) and IBGE (2011).

indicators of environmental impact, global spread, and scope (Goedkoop et al., 2009). Some works have applied LCA on different beef production systems (Beauchemin et al., 2010; Nguyen et al., 2010; Ogino et al., 2007, 2004) or scenarios (Beauchemin et al., 2011). Factors such as the geography and the adopted time scale (Casey and Holden, 2006) punctuate the flexibility of this analysis and the care necessary for interpretation.

In Brazil, farming systems occupy approximately 160 million hectares (IBGE, 2012) and are home to the largest commercial cattle herd in the world. The herd is maintained almost exclusively on pasture with a negligible use of external inputs to production units. The southern Brazil has practiced cattle farming since its colonization, and the economy is heavily based on primary cattle production. The region is in a privileged position, the climatic conditions are favorable for keeping the animals in pastures year around, but nevertheless no LCA studies on whole farm level has so far been developed for a regional beef production (Ruviaro et al., 2012).

This work analyzes the main environmental impacts of two typical beef cattle production systems from southern Brazil: the extensive system (ES) and the improved system (IS). Additionally, it identifies the components and processes that have the greatest environmental impact in terms of (a) global warming, (b) land use, (c) freshwater depletion, (d) metal depletion; (d) fossil depletion, (e) terrestrial acidification and (f) freshwater eutrophication.

\section{Methods}

Life cycle assessment (LCA) has been described by the definitions of standards ISO14040 (2006) and ISO14044 (2006). Our analysis involves different levels of organization, which are limited to environmental aspects, and does not consider social and economic issues.

\subsection{The system boundaries and functional unit}

According to IBGE (2011), the southern Brazil has a cattle herd of 27.98 million head, and more than half of these are found in Rio Grande do Sul State, particularly in the Pampa biome (Fig. 1). In this biome, the dominant vegetation is natural grasslands with predominant Paspalum, Axonopus, Briza and Bromus species, sparse shrubs and trees. The climate is humid subtropical with welldefined seasons. The frequent soil types are Mollisols, Vertisols and Ultisols, and these are usually well drained with limitations due to low natural fertility, acidity and susceptibility to erosion and degradation. We simulated the representative properties in this ecoregion, which is localized between $29^{\circ} 30^{\prime}$ and $32^{\circ} 30^{\prime}$ south latitude and $52^{\circ} 10^{\prime}$ and $57^{\circ} 40^{\prime}$ west longitude.

The LCA was conducted over several years in order to represent the emissions of the entire cycle, as well as of all components of the beef production. The systems include the following: animals; native grassland and pastures improved by the introduction of winter grasses (ryegrass and oat) and leguminous (clover and birdsfoot trefoil); potassium and phosphorous fertilization, liming, and mowing; supplementation (common and mineral salt); and the resources used to produce these components (minerals, fuels, etc.) and; the transport of different materials, both externally and internally, to the production unit (Figs. 2 and 3). Emissions associated with capital goods (machinery, buildings, etc.) and medicines were not considered.

In the description of the pastures, we considered issues related to the occupation and transformation of land, the energy used to forage production, the mineral flows and other substances that exert potential impacts on environmental parameters. With respect to the water supply to the animals, data related to the use of natural water in the extensive system and the use of troughs in the improved system was considered. In this case, the energy required for water distribution was added to the process. In regard to common or mineral salt supplementation, data were computed on the raw materials, their transportation to the production unit, and on farm supply. The energy used, the estimated impact of the materials, the mechanized operations, and the transportation of the

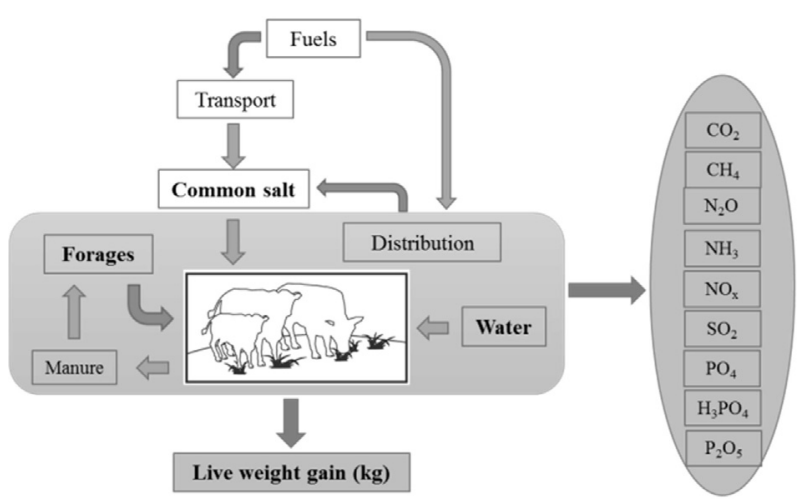

Fig. 2. Systems boundary - extensive system. 


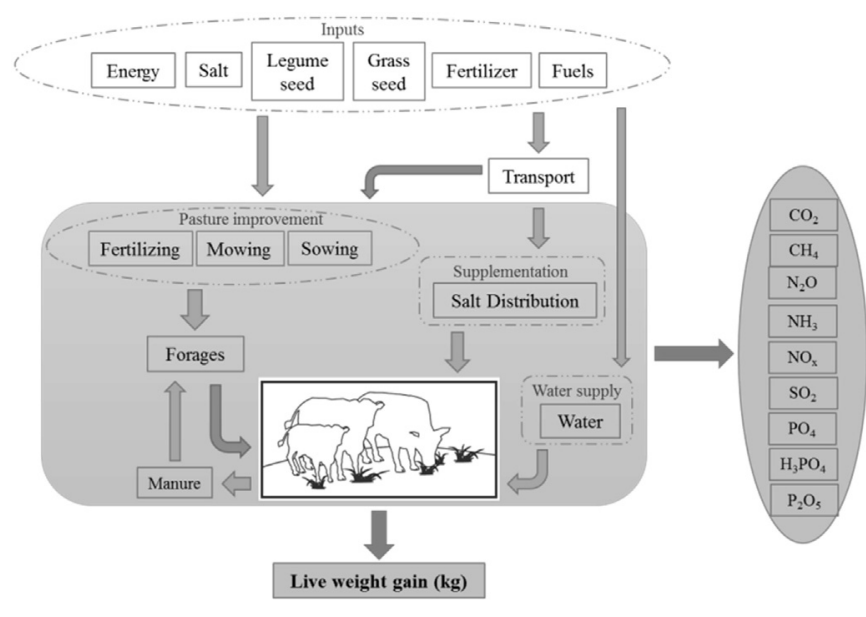

Fig. 3. Systems boundary - improved system.

system components for both systems were based on secondary data from the Ecoinvent and LCAfood databases, incorporated into software SimaPro version 7.3.3 (Goedkoop et al., 2010), used for structuring the analysis.

Table 1

Main characteristics assumed for the herds of the extensive and improved systems.

\begin{tabular}{|c|c|c|c|}
\hline \multirow[t]{2}{*}{ Descriptions } & \multicolumn{2}{|l|}{ System } & \multirow[t]{2}{*}{ References/sources } \\
\hline & Extensive & Improved & \\
\hline \multicolumn{4}{|l|}{ Herd structure } \\
\hline $\begin{array}{l}\text { Weaned calves } \\
\text { weight }(\mathrm{kg})\end{array}$ & 170 & 210 & $\begin{array}{l}\text { Corrêa, 2001; Euclides } \\
\text { Filho, 2000; Oliveira et } \\
\text { al., } 2006 .\end{array}$ \\
\hline $\begin{array}{c}\text { Weaned heifers } \\
\text { weight }(\mathrm{kg})\end{array}$ & 150 & 190 & $\begin{array}{l}\text { Corrêa, 2001; Euclides } \\
\text { Filho, 2000; Oliveira } \\
\text { et al., } 2006 .\end{array}$ \\
\hline $\begin{array}{l}\text { Replacement rate } \\
(\% / y)\end{array}$ & 20 & 12,5 & $\begin{array}{l}\text { Corrêa, 2001; Euclides } \\
\text { Filho, } 2000 .\end{array}$ \\
\hline Weaning rate (\%) & 55 & 78 & Euclides Filho, 2000. \\
\hline Mortality rate (\%) & 4 & 1 & $\begin{array}{l}\text { Corrêa, 2001; Euclides } \\
\text { Filho, } 2000 .\end{array}$ \\
\hline Male-female ratio & $1: 1$ & $1: 1$ & - \\
\hline $\begin{array}{l}\text { Weight gain first } \\
\text { year }(\mathrm{kg} / \mathrm{d})\end{array}$ & 0.1 & 0.2 & Kichel et al., 2011. \\
\hline Weight gain $(\mathrm{kg} / \mathrm{d})$ & 0.23 & 0.6 & $\begin{array}{l}\text { Euclides Filho, } 2000 \text {, } \\
\text { Kichel et al., } 2011 .\end{array}$ \\
\hline $\begin{array}{l}\text { First calving } \\
\text { (months) }\end{array}$ & 48 & 30 & $\begin{array}{l}\text { Corrêa, 2001; Euclides } \\
\text { Filho, 2000; Kichel } \\
\text { et al., } 2011 .\end{array}$ \\
\hline $\begin{array}{l}\text { Milk production } \\
\quad(\mathrm{l} / \text { head/d })\end{array}$ & 1.1 & 2.2 & Euclides Filho, 2000. \\
\hline $\begin{array}{l}\text { Slaughter weight - } \\
\text { males }(\mathrm{kg})\end{array}$ & 440 & 500 & $\begin{array}{l}\text { Kichel et al., 2011; Lima } \\
\text { et al., } 2002 .\end{array}$ \\
\hline $\begin{array}{l}\text { Slaughter weight - } \\
\text { females (kg) }\end{array}$ & 420 & 480 & $\begin{array}{l}\text { Kichel et al., 2011; Lima } \\
\text { et al., } 2002 .\end{array}$ \\
\hline $\begin{array}{l}\text { Body weight, bulls } \\
\quad(\mathrm{kg})\end{array}$ & 600 & 700 & $\begin{array}{l}\text { Kichel et al., 2011; Lima } \\
\text { et al., } 2002 .\end{array}$ \\
\hline $\begin{array}{l}\text { Body weight, cows } \\
\quad(\mathrm{kg})\end{array}$ & 380 & 400 & $\begin{array}{l}\text { Kichel et al., 2011; Lima } \\
\text { et al., } 2002 .\end{array}$ \\
\hline $\begin{array}{l}\text { Forage intake } \\
\quad(\mathrm{kg} \mathrm{DM} / \mathrm{head} / \mathrm{d})\end{array}$ & 8.1 & 9.99 & NRC, 2000 \\
\hline $\begin{array}{l}\text { Water } \\
\text { consumption } \\
\text { (l/head/d) }\end{array}$ & 50 & 50 & Nunes, 1998. \\
\hline $\begin{array}{l}\text { Common salt } \\
\text { consumption } \\
\text { (g/head/d) }\end{array}$ & 50 & - & Lalman and Doye, 2005. \\
\hline $\begin{array}{l}\text { Mineral salt } \\
\text { consumption } \\
\text { (g/head/d) }\end{array}$ & - & 150 & Lalman and Doye, 2005. \\
\hline Manure handling & $\begin{array}{l}\text { On } \\
\text { pasture }\end{array}$ & $\begin{array}{l}\text { On } \\
\text { pasture }\end{array}$ & - \\
\hline
\end{tabular}

$\mathrm{d}=$ day; DM = dry matter; $\mathrm{y}=$ year.
The functional unit of production (FU) was defined as $1 \mathrm{~kg}$ of live weight gain (LWG) at the farm-gate. For reference comparisons, the carcass weight was assumed to be $50 \%$ of the total live weight.

\subsection{Description of the systems}

The description of typical situations, namely the extensive system (ES) and the improved system (IS), was based on bibliographic references with emphasis on local beef production data (Tables 1 and 2).

The animal population of systems was estimated from the simulation of herd evolution as recommended by IPCC (2006b), tier 2 . The LCA began when the initial animals were weaned, continued through the meat production cycles, and ended when the initial cows and bulls were fully replaced.

\subsubsection{Extensive system (ES)}

The extensive beef production system represents the traditional South Brazilian pastoral system and its peculiarities. The main feature of the ES is the use of large tracts of land with little or no subdivision; where the animals are able to continuously graze on the natural pasture throughout the year with little or no supplementation. The forage production is strongly affected by climatic variations. The grazing areas are often degraded due to low forage availability, and characterized by the presence of bare ground, erosion, mound proliferation, and an increasing accumulation of less palatable plants, depending on the diet selection of the animals. These aspects, which added to the various sanitary and reproductive problems, place the overall performance of the regional cattle at risk. The production rates are low, leading to an excessive permanence time of the animals in the system (Lima et al., 2002).

The simulated production unit used in this work consisted of a herd with originally one hundred weaned heifers and four weaned

Table 2

Basic assumption for the grassland of the extensive and improved systems.

\begin{tabular}{|c|c|c|c|}
\hline \multirow[t]{2}{*}{ Grassland } & \multicolumn{2}{|l|}{ Systems } & \multirow[t]{2}{*}{ References/sources } \\
\hline & Extensive & Improved & \\
\hline \multicolumn{4}{|l|}{ Composition } \\
\hline Pasture type & $\begin{array}{l}\text { Native } \\
\text { pasture }\end{array}$ & $\begin{array}{l}\text { Native pasture } \\
\text { with winter } \\
\text { grasses and } \\
\text { leguminous }\end{array}$ & $\begin{array}{l}\text { Blanco et al., 2007; } \\
\text { Santos et al., 2006; } \\
\text { Teixeira e Abreu } \\
\text { da Silva, } 2007 .\end{array}$ \\
\hline Winter species & - & $\begin{array}{l}\text { Ryegrass, oat, } \\
\text { clover and } \\
\text { birdsfoot trefoil }\end{array}$ & $\begin{array}{l}\text { Gonzalez et al., 2009; } \\
\text { Krolow et al., 2012; } \\
\text { Pedroso et al., } 2004 .\end{array}$ \\
\hline \multicolumn{4}{|l|}{ Implementation } \\
\hline $\begin{array}{l}\text { Phosphorus fertilization } \\
\qquad\left(\mathrm{kg} \mathrm{P}_{2} \mathrm{O}_{5} / \mathrm{ha} / 2 \mathrm{y}\right)\end{array}$ & - & 100 & Siqueira et al., 1987. \\
\hline $\begin{array}{l}\text { Potassium fertilization } \\
\quad\left(\mathrm{kg} \mathrm{K} \mathrm{K}_{2} \mathrm{O} / \mathrm{ha} / 2 \mathrm{y}\right)\end{array}$ & - & 130 & Siqueira et al., 1987. \\
\hline Liming (ton/ha/6y) & - & 2 & Siqueira et al., 1987. \\
\hline Mowing/y & - & 1 & Expert opinion \\
\hline Overseed/2y & - & 1 & Expert opinion \\
\hline Seed grass $(\mathrm{kg} / 2 \mathrm{y})$ & - & 40 & Expert opinion \\
\hline Seed leguminous $(\mathrm{kg} / 2 \mathrm{y})$ & - & 10 & Expert opinion \\
\hline \multicolumn{4}{|l|}{ Parameters quality } \\
\hline Production (kg DM/ha/y) & 3000 & 11500 & $\begin{array}{l}\text { Maraschin, 2001; } \\
\text { Scholl et al., } 1976\end{array}$ \\
\hline $\begin{array}{l}\text { Digestibility energy } \\
\text { (\% DM) }\end{array}$ & 47 & 55 & Lima et al., 2002. \\
\hline Crude Protein (\% DM) & 12 & 15 & Lima et al., 2002. \\
\hline Ym factor (\% GE intake) & 7.2 & 6.5 & IPCC, 2006b. \\
\hline $\begin{array}{l}\text { Forage utilization } \\
\quad \text { efficiency }(\%)\end{array}$ & 50 & 70 & Maraschin, 2001. \\
\hline
\end{tabular}

$\mathrm{DM}=$ dry matter; $\mathrm{GE}=$ gross energy; $\mathrm{y}=$ year. 
calves with an average age of six months, and the progeny obtained during the productive life of these females, assuming an average replacement rate of $20 \%$ per year, over a 12 -year period, which was determined by the availability of animals for replacement (Fig. 4).

\subsubsection{Improved system}

The improved system has lower impacts of seasonal grassland production of native pastures with increased forage production and feed quality (Gonzalez et al., 2009; Krolow et al., 2012), as a result of the introduction of winter forage species and weekly rotational grazing. This introduction and the improvement of pasture management have relatively low cost and provides increases in production rates (Teixeira and Abreu da Silva, 2007).

The herd evolution was performed using a method similar to that in the ES; thus, a starting point of one hundred heifers and four calves, which were weaned at an average age of six months, was used, and the system was studied over 12 years (Tables 1 and 2, and Fig. 4).

\subsection{Environmental inventory}

Resource inputs for and emissions from the use of pastures, the cultivation of forages, the manure handling, and the enteric fermentation by cattle were estimated. Equations and assumptions used for the estimation of emissions were summarized in Table 3. Resource inputs for and emissions from fertilizer and supplementation production were taken from Nemecek and Kägi (2007). All transport operations including transport of agricultural production inputs from a local storehouse to the farm were assumed to be realized using a truck 28t (Frischknecht et al., 2007), in an average distance of $0.25 \mathrm{tkm}$ (ton-kilometers). From all energy inputs for process, the Brazilian average electricity mix from Frischknecht et al. (2007) was used. Resource inputs for and emissions from the internally mechanized operations were based on Jungbluth et al. (2007).

\subsubsection{Main calculated sources of emissions from extensive and} improved systems

The greenhouse gas emissions (GHG) for each system were estimated according to animal categories for the entire period (12
Table 3

Assumptions used for calculation of emissions.

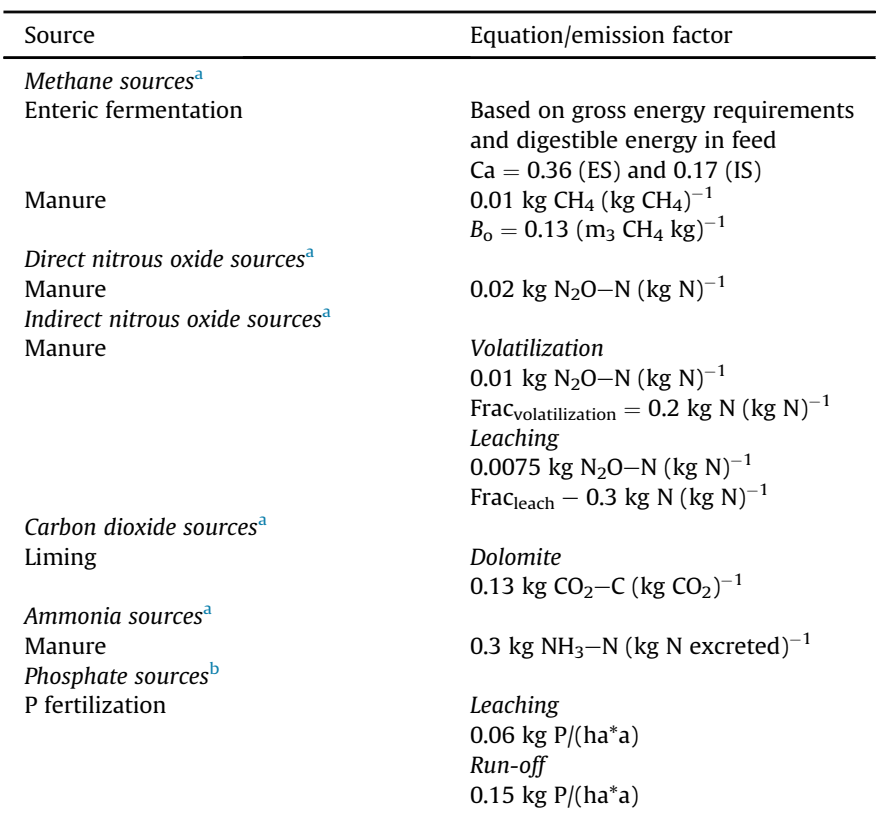

$B_{0}=$ methane producing capacity by manure produced relative to Latin America; $\mathrm{Frac}_{\text {volatilization }}=$ volatilization fraction; $\mathrm{Frac}_{\text {leach }}=$ leaching fraction .

a IPCC, 2006b.

b Nemecek and Kägi, 2007.

years) and per kg of LWG. The GHG included the methane emissions $\left(\mathrm{CH}_{4}\right)$, which were derived from enteric fermentation and the excreta of animals, the direct and indirect nitrous oxide emissions $\left(\mathrm{N}_{2} \mathrm{O}\right)$ from the disposal of the excreta of grazing animals, and the carbon dioxide $\left(\mathrm{CO}_{2}\right)$ balance, which assume that the soil carbon (C) stock is in steady state. The biological $\mathrm{N}$ fixation was estimated at $100 \mathrm{~kg} \mathrm{~N} / \mathrm{ha} / \mathrm{y}$ (Rattray, 2005) and the $\mathrm{N}_{2} \mathrm{O}$ emissions were considered as suggested by IPCC (2006a). The $\mathrm{CO}_{2}$ emissions from livestock are not estimated because annual net $\mathrm{CO}_{2}$ emissions are assumed to be zero - the $\mathrm{CO}_{2}$ photosynthesized by plants is returned to the atmosphere as respired $\mathrm{CO}_{2}$ (IPCC, 2006b).

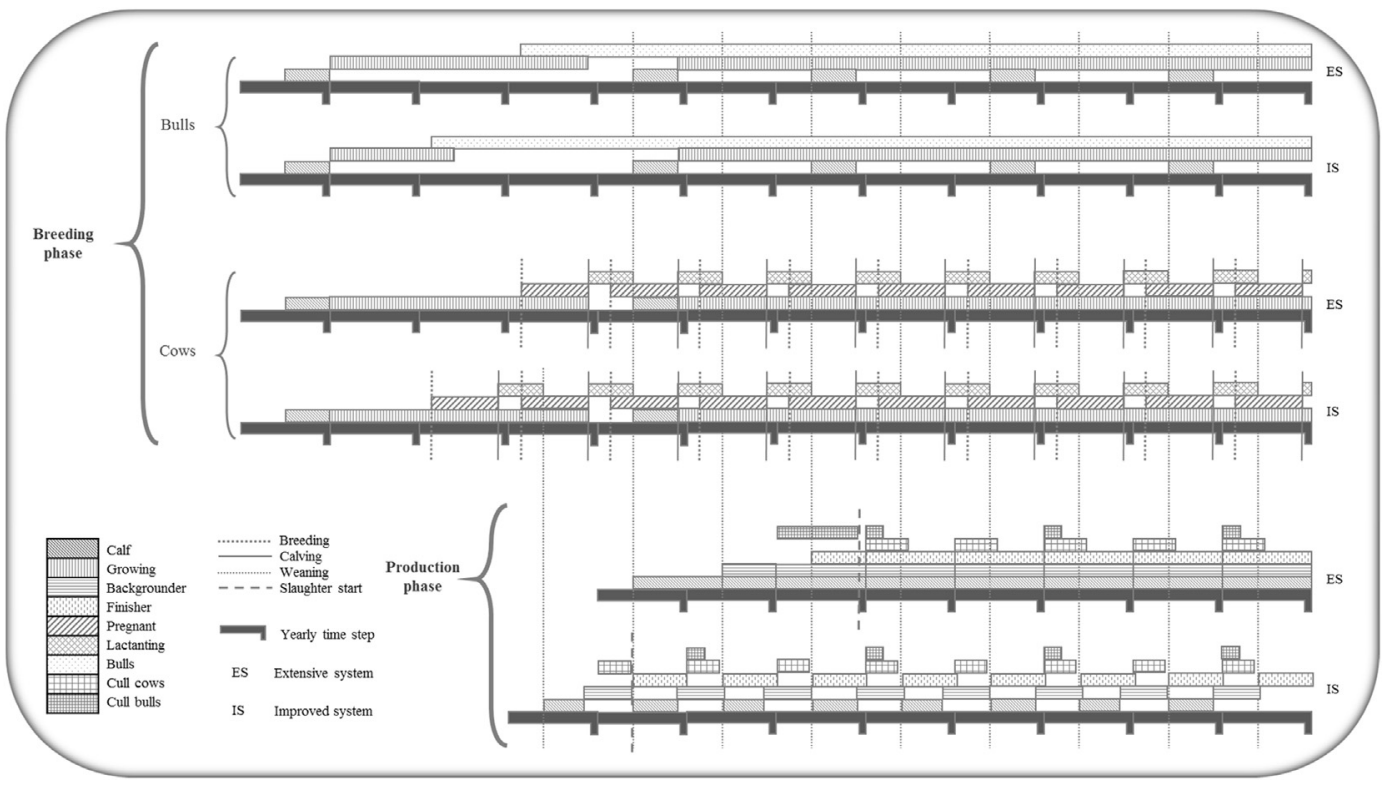

Fig. 4. Herd evolution of extensive (ES) and improved (IS) systems. 
Enteric $\mathrm{CH}_{4}$ emissions were calculated for each class of cattle according to the IPCC (2006b), tier 2 methodology. Daily net energy requirements for cattle in each stage of production were estimated from energy expenditures for maintenance, activity, growth, pregnancy, lactation and work as appropriate. The gross energy (GE) intake required to meet energy requirements was then estimated taking into account the energy density of the diet (IPCC, 2006b), and enteric $\mathrm{CH} 4$ emissions were calculated from gross energy intake using the $\mathrm{CH}_{4}$ conversion factors (Ym) for each diet.

Methane emissions from manure were based on volatile solids production, according to IPCC (2006b), taking into account the GE intake of the animal and the digestibility of the diet. Volatile solid production was multiplied by a maximum $\mathrm{CH}_{4}$ producing capacity of the manure (Bo) and a $\mathrm{CH}_{4}$ conversion factor specific to the manure management practice used.

Manure $\mathrm{N}$ was estimated from dry matter intake (DMI) and the crude protein $(\mathrm{CP})$ content of the diet, and $\mathrm{N}$ retention of the animals based on IPCC (2006b) and NRC (2000). Manure N content was multiplied by an emission factor for the manure handling system (deposited on pasture) to calculate direct $\mathrm{N}_{2} \mathrm{O}$ emissions (IPCC, 2006b). Indirect $\mathrm{N}_{2} \mathrm{O}$ emissions from $\mathrm{N}$ lost from the farm via run-off, leaching and volatilization is also included. These emissions were estimated from the assumed fractions of $\mathrm{N}$ lost from manure, residues, and fertilizer, adjusted for climatic conditions as detailed by Lima et al. (2002), and the IPCC (2006a) emission factor.

\subsection{Environmental assessment}

The grouping and conversion of different interventions in potential environmental impacts were performed using the Recipe midpoints method, version 1.6, included in SimaPro 7.3.3 software, using the normalization standard World $\mathrm{H}$; hierarchist perspective.

The impact categories and environmental indicators were selected for their demonstrated relevance in similar studies by other authors (Haas et al., 2001; Ogino et al., 2007) and as suggested by international institutions to be used in ACV studies (Consoli, 1993; ISO14044, 2006). Although the Recipe method enabled the evaluation of 18 impact categories, the emphasis of this study was on: global warming $(\mathrm{kg} \mathrm{CO} 2 \mathrm{eq})$, land occupation $\left(\mathrm{m}^{2} \mathrm{a}\right)$, terrestrial acidification ( $\mathrm{kg} \mathrm{SO} \mathrm{S}_{2} \mathrm{eq}$ ), freshwater eutrophication ( $\mathrm{kg} \mathrm{P}$ eq), and depletion of freshwater $\left(\mathrm{m}^{3}\right)$, metal ( $\mathrm{kg} \mathrm{Fe}$ eq) and fossil ( $\mathrm{kg}$ oil eq).

To determine the potential impact in each category used, we adopted the following characterization factors: global warming $\mathrm{kg} \mathrm{CO} 2 \times 1, \mathrm{~kg} \mathrm{CH}_{4} \times 22$, and $\mathrm{kg} \mathrm{N}_{2} \mathrm{O} \times 298$ with a global warming potential in a time horizon of 100 years (GWP 100); terrestrial acidification $-\mathrm{kg} \mathrm{SO}_{2} \times 1, \mathrm{~kg} \mathrm{SO} \times 1, \mathrm{~kg} \mathrm{NH}_{3} \times 2.45$, and $\mathrm{kg}$ $\mathrm{NO}_{\mathrm{x}} \times 0.56$; freshwater eutrophication $-\mathrm{kg} \mathrm{P} \times 1, \mathrm{~kg} \mathrm{PO}_{4} \times 0.33, \mathrm{~kg}$ $\mathrm{H}_{3} \mathrm{PO}_{4} \times 0.32$ and $\mathrm{kg} \mathrm{P}_{2} \mathrm{O}_{5} \times 0.44$; and resource depletions according to Goedkoop et al. (2009) - update 1.6.

\section{Results}

\subsection{Life cycle inventory}

Emissions of $\mathrm{CH}_{4}$ and $\mathrm{N}_{2} \mathrm{O} / \mathrm{kg}$ LWG are lower by 37.64 and $60.78 \%$ respectively for the IS than for the ES (Table 4 ). All other gaseous emissions prevail at the IS, except the $\mathrm{CO}_{2}$ fossil due to the effect of $\mathrm{N}$ fixation by legumes. Outputs of phosphate and phosphorus to water are also lower in IS (58.23 and $18.52 \%$ of the emissions obtained in ES).

\subsection{Life cycle impact assessment}

With regard to environmental impact, the ES presents higher values associated with global warming, land occupation,
Table 4

Main emissions for $1 \mathrm{~kg}$ of live weight gain of the extensive and improved systems.

\begin{tabular}{lcc}
\hline Emissions & Systems & \\
\cline { 2 - 3 } & Extensive & Improved \\
\hline Methane biogenic (g) & 866 & 326 \\
Dinitrogen monoxide (g) & 11.6 & 7.05 \\
Carbon dioxide (g) & 11.3 & 54.7 \\
Carbon dioxide, fossil (g) & - & -183 \\
Sulfur dioxide (g) & - & 2.51 \\
Nitrogen oxides (g) & 2.61 & 3.51 \\
Sulfur oxide (mg) & 26.9 & 130 \\
Ammonia (mg) & 552 & -342 \\
Phosphate (g) & 11.3 & 6.58 \\
Phosphorus (mg) & 108 & 20 \\
\hline
\end{tabular}

freshwater eutrophication, freshwater depletion, and fossil depletion. However, the IS presents higher impacts in the categories of metal depletion and terrestrial acidification (Table 5 and Fig. 5).

\subsubsection{Global warming}

The GHG emissions in the ES were $22.52 \mathrm{~kg} \mathrm{CO} 2 \mathrm{eq} / \mathrm{kg}$ LWG, and of these, $19.05 \mathrm{~kg} \mathrm{CO} 2 \mathrm{eq} / \mathrm{kg}$ LWG were from animals, $3.46 \mathrm{~kg} \mathrm{CO}$ eq $/ \mathrm{kg}$ LWG were due to native grassland, and $0.0121 \mathrm{~kg} \mathrm{CO} 2 \mathrm{eq} / \mathrm{kg}$ LWG were related to mineral supplementation (common salt). The IS, however, presented a total GHG emission value of $9.16 \mathrm{~kg} \mathrm{CO} 2 \mathrm{eq} /$ $\mathrm{kg}$ LWG. Of these emissions, 7.16, 1.91, and $0.0923 \mathrm{~kg} \mathrm{CO} 2 \mathrm{eq} / \mathrm{kg}$ LWG were due to animals, forages and, mineral salts and water supply, respectively.

The GHG emissions/kg LWG in the IS was found to be $40.67 \%$ of the emissions obtained in ES. The difference between the two systems is due to the lower quality of the forage consumed by the animals in the ES compared with the IS and is based on the differences in dry matter (DM) intake/animal/day, the Ym, the digestibility, and the pasture use efficiency related to the time required to produce $1 \mathrm{~kg}$ LWG. These characteristics have a significant impact on the emissions per $\mathrm{kg}$ of body weight as the total emissions of each system (Table 6). These values corroborate assertions from Bartl et al. (2011) and Cederberg et al. (2009) on the possibility of GHG reduction through productive increments, through both pasture management improvement and productive herd indices.

Of the GHG emissions from the animals, $97.27 \%$ and $97.35 \%$ were due to enteric fermentation ( 18.53 and $6.97 \mathrm{~kg} \mathrm{CO}_{2} \mathrm{eq} / \mathrm{kg}$ LWG in ES and IS, respectively). Of the total GHG emissions, 63.38\% and $61.65 \%$ (14.27 and $5.65 \mathrm{~kg} \mathrm{CO} 2 \mathrm{eq} / \mathrm{kg}$ LWG, respectively in ES and IS) were from the animal categories that constitute the breeding herd.

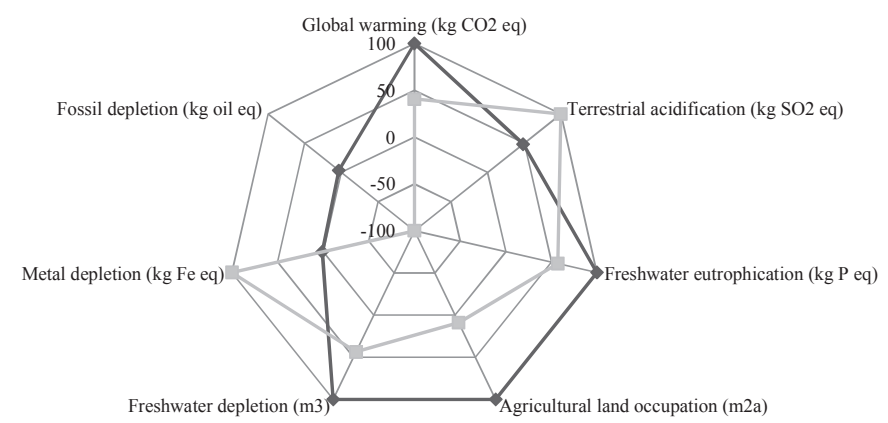

$\multimap$ extensive system (ES) $\quad \longrightarrow$ - improved system (IS)

Fig. 5. Inventory (schematic) of environment impact categories in extensive and improved systems: expressed in percentage $(100 \%=$ maximum absolute values). 
Table 5

Environmental impacts (\%) of extensive and improved systems.

\begin{tabular}{|c|c|c|c|c|c|c|c|c|}
\hline \multirow[t]{2}{*}{ Impact (\%) } & \multicolumn{4}{|c|}{ Extensive } & \multicolumn{4}{|c|}{ Improved } \\
\hline & Animal & Grassland & Salt & Water & Animal & Grassland & Salt & Water \\
\hline Global warming & 84.57 & 15.38 & 0.05 & - & 78.14 & 20.85 & 0.15 & 0.86 \\
\hline Agricultural land occupation & - & 100 & - & - & - & 99.99 & - & 0.01 \\
\hline Terrestrial acidification & 48.24 & 48.94 & 3.11 & - & 18.94 & 76.39 & 2.71 & 1.92 \\
\hline Freshwater eutrophication & - & 100 & - & - & - & 99.74 & - & 0.26 \\
\hline Freshwater depletion & - & - & 0.04 & 99.96 & - & 11.94 & 0.10 & 87.96 \\
\hline Metal depletion & - & - & 100 & - & - & 35.79 & 61.07 & 3.14 \\
\hline Fossil depletion & - & - & 100 & - & - & -111.40 & 3.84 & 7.56 \\
\hline
\end{tabular}

\subsubsection{Agricultural land occupation}

We obtained land occupation values of 234.78 and $21 \mathrm{~m}^{2} \mathrm{a} / \mathrm{kg}$ LWG for the ES and IS systems, respectively, which correspond to the differences between the two systems in terms of production and the time needed to obtain $1 \mathrm{~kg}$ of LWG (4.35 and 1.67 days, respectively, in the ES and IS), due to LWG differences (0.23 and $0.6 \mathrm{~kg} / \mathrm{LWG} /$ day, respectively, in the ES and IS). The better land use, as a consequence of a larger production performance, results in a lower pressure associated with the use of sensitive areas presents in the production units. As postulated by Cederberg et al. (2009), such improvements cooperate to stop or even reverse the expansion of production in ecosystems where there is a clear interest in maintaining the natural condition. Note that the large variation in the systems is an advantage for the reduction land requirements for meat production (Elferink and Nonhebel, 2007).

\subsubsection{Freshwater depletion}

In the ES, the freshwater depletion was $0.217 \mathrm{~m}^{3} / \mathrm{kg}$ LWG. This value is mainly attributed to the relatively large consumption by the animals because 4.35 days are required to produce $1 \mathrm{~kg}$ of live weight. In the IS, the freshwater depletion was $0.0949 \mathrm{~m}^{3} / \mathrm{kg}$ LWG. Of this value, $0.08 \mathrm{~m}^{3} / \mathrm{kg}$ LWG were due to animal consumption, and the deployment of cultivated pastures and mineral supplementation contributed with 0.011 and $9.69 \mathrm{E}-5 \mathrm{~m}^{3} / \mathrm{kg}$ LWG, respectively.

\subsubsection{Metal depletion}

With respect to metal depletion, the ES presented a lower potential impact than the IS (0.000519 and $0.0536 \mathrm{~kg} \mathrm{Fe} \mathrm{eq/kg} \mathrm{LWG,}$ respectively). These values were related to the supply of salt to animals in the ES. In the IS, the values were $0.033 \mathrm{~kg}$ Fe eq $/ \mathrm{kg}$ LWG due to supplementation, $0.02 \mathrm{~kg} \mathrm{Fe} \mathrm{eq} / \mathrm{kg}$ LWG due to deployment of pastures, and $0.002 \mathrm{~kg}$ Fe eq/ $\mathrm{kg}$ LWG due to distribution of water in the troughs.

\subsubsection{Fossil depletion}

The fossil depletion values for both systems exhibit two different situations. The ES had a fossil depletion of $0.0042 \mathrm{~kg}$ oil eq $/ \mathrm{kg}$ LWG due to the external transport of salt to the production unit. The IS had a fossil depletion of $-0.1255 \mathrm{~kg}$ oil eq $/ \mathrm{kg}$ LWG. In this case, the introduction of leguminous plants over the use of synthetic nitrogen fertilizers defined the impact on fossil depletion

Table 6

Total GHG emissions and beef production in extensive and improved systems during 12 years.

\begin{tabular}{|c|c|c|c|c|}
\hline & \multirow{2}{*}{$\frac{\text { GHG emissions }}{\left(t \mathrm{CO}_{2} \text { eq }\right)}$} & \multirow{2}{*}{$\begin{array}{l}\text { Beef production }(\mathrm{kg}) \\
\begin{array}{l}\text { Live weight } \\
\text { gain }\end{array}\end{array}$} & \multicolumn{2}{|c|}{ GHG intensity $(\mathrm{kg} \mathrm{CO} 2 \mathrm{eq} / \mathrm{kg}$ ) } \\
\hline & & & $\begin{array}{l}\text { Live weight } \\
\text { basis }\end{array}$ & $\begin{array}{l}\text { Carcass weight } \\
\text { basis }\end{array}$ \\
\hline ES & 2536.37 & 112610.63 & 22.52 & 45.05 \\
\hline IS & 1959.61 & 213964.52 & 9.16 & 18.32 \\
\hline
\end{tabular}

because the effect of $\mathrm{N}$ fixation more than offset all contributions from other activities.

\subsubsection{Terrestrial acidification}

The ES presented a lower terrestrial acidification potential compared with the IS (0.0028 and $0.0038 \mathrm{~kg} \mathrm{SO}$ eq/ $/ \mathrm{kg} \mathrm{LWG),}$ respectively. In the $\mathrm{ES}$, the pasture, the animals, and the supply of salt constituted $0.0014,0.0014$, and $8.83 \mathrm{E}-5 \mathrm{~kg} \mathrm{SO}$ eq/kg LWG, respectively. In the IS, the values attributed to the pasture, animals, mineral supplementation, and water supply were 0.0029, 0.0007, 0.0001 , and $7.25 \mathrm{E}-5 \mathrm{~kg} \mathrm{SO}{ }_{2} \mathrm{eq} / \mathrm{kg} \mathrm{LWG}$, respectively.

\subsubsection{Freshwater eutrophication}

The values of freshwater eutrophication per unit of LWG were higher in the ES than in the IS ( 0.00383 and $0.00219 \mathrm{~kg} \mathrm{P} \mathrm{eq),} \mathrm{due} \mathrm{to}$ the multiplier effect of the increased permanence time of the animals in the ES despite the potential increment of P flows as a result of the $\mathrm{P}$ fertilization observed in the IS. The nutrient losses from pastures defined these values in both systems.

\section{Discussion}

To contextualize the results obtained in this work, we sought to compare these results with those obtained from different production systems and regions of the world; however, LCA results are difficult to compare. De Vries and De Boer (2010) and Yan et al. (2013) warned that some studies consider the emissions or removals due to land use whereas others do not, and some works adopt a "cradle to grave" approach, whereas other studies use a "cradle to gate" approach. Even considering similar objects of analysis, differences in terms of the functional unit definition, allocation methods, and the characterization of the processes were observed (Halberg et al., 2005).

\subsection{Global warming}

The analysis of the contribution of the breeding herd to the total GHG emissions showed that the values obtained in this work (63.38\% and 61.65\%) are similar to the results found by StackhouseLawson et al. (2012) in a study conducted in California, USA, in which the establishing step accounted for $69 \%-72 \%$. Those values and the results obtained by Beauchemin et al. (2010) in Canada (80\%) are, however, higher than the values observed in this study. Those studies had more intense production systems in which the growing and finishing phases present a lower contribution to the total emissions, thereby increasing the importance of the breeding stock phase.

In the present work, enteric fermentation accounts for larger shares of the total GHG emissions, making up $84.57 \%$ and $78.14 \%$ of the GHG emissions in the ES and IS, respectively, compared with those seen in different production systems in the European Union (EU), Canada and Japan, where enteric fermentation makes up 
32\%-42\% (Weiss and Leip, 2012), 48.16\% (Mc Geough et al., 2012), and $61.2 \%$ (Ogino et al., 2007) of the total emissions, respectively. The lower fraction of enteric emissions obtained by these authors is due to the greater contribution of emissions from manure management and animal production with large amounts of concentrates.

With respect to the total GHG emissions, our results (22.5 and $9.16 \mathrm{~kg} \mathrm{CO} 2 \mathrm{eq} / \mathrm{kg}$ LWG for the ES and IS) are similar to the values obtained by Dollé et al. (2011) in French production. In their work, the authors found values between 14.8 and $16.5 \mathrm{~kg} \mathrm{CO} 2 \mathrm{eq} / \mathrm{kg} \mathrm{LW}$ and noted the possibility of a $24 \%$ and $53 \%$ reduction of the emissions by the carbon sequestration that occurs in pastures and bush formations, which would result in values between 7.9 and $11.3 \mathrm{~kg}$ $\mathrm{CO}_{2} \mathrm{eq} / \mathrm{kg} \mathrm{LW}$. These effects were not included in our analyses.

Assuming the production of $1 \mathrm{~kg}$ of hot standard carcass weight (HSCW) as a functional unit and considering a carcass yield of $50 \%$, our results ( 18.32 and $45.05 \mathrm{~kg} \mathrm{CO} 2 \mathrm{eq} / \mathrm{kg} \mathrm{HSCW}$ for IS and ES) replicate the range of values observed in intensive production systems, which characterize the developed countries, and extensive systems, which are found in other countries. Similarly, Weiss and Leip (2012) obtained 14.2 and $17.4 \mathrm{~kg} \mathrm{CO}$ eq/kg HSCW in Austria and the Netherlands, and values above $40 \mathrm{~kg} \mathrm{CO}$ eq $/ \mathrm{kg}$ HSCW in more extensive systems on the island of Cyprus and in Latvia. Nguyen et al. (2010) found $27.3 \mathrm{~kg} \mathrm{CO} 2 \mathrm{eq} / \mathrm{kg} \mathrm{HSCW}$ to be the average value of EU suckler herds. Depending on the production management, Stackhouse-Lawson et al. (2012) found variations in the emissions from 10.7 to $22.6 \mathrm{~kg}$ of $\mathrm{CO}_{2} \mathrm{eq} / \mathrm{kg} \mathrm{HSCW}$ in California. Thereby, productive improvements emerge as essential possibilities to mitigate the environmental impacts of livestock production systems as reported by Capper et al. (2009a, and 2009b).

\subsection{Agricultural land occupation}

The IS value obtained in this work $\left(42 \mathrm{~m}^{2} \mathrm{a}\right)$ for land occupation, which is expressed per $\mathrm{kg}$ HSCW, is similar to that proposed by Nguyen et al. (2010) as the mean value of EU suckler herds (42.9 $\mathrm{m}^{2} \mathrm{a}$ ). The comparison between the observed values for the ES $\left(469.56 \mathrm{~m}^{2} / \mathrm{kg} \mathrm{HSCW}\right)$ and the IS results in a similar ratio (ES/ IS $=11.2$ ) to that obtained by Bartl et al. (2011), who compared two livestock systems typical of Peru, with different degrees of intensity (13.5). Higher values of land use in more extensive systems have been observed by other authors including Arsenault et al. (2009), who compared 11 impact categories of production systems on the pasture and feedlot in Nova Scotia, Canada, and obtained a greater impact of grazing systems only in this category.

To emphasize the importance of land use and the influence of land use changes on other environmental aspects, Weiss and Leip (2012) estimated that a total of $21-28 \mathrm{~kg}$ of $\mathrm{CO}_{2} \mathrm{eq} / \mathrm{kg} \mathrm{HSCW}$ is characteristic of EU beef production and that $2.9-9.4 \mathrm{~kg}$ of $\mathrm{CO}_{2} \mathrm{eq} /$ $\mathrm{kg} \mathrm{HSCW}$ is caused by changes introduced by cropping systems in land use. This is due to the significant demand for concentrated feed for the European livestock systems that, according to these authors, configure different scenarios of carbon emission into the atmosphere, including, in the most pessimistic outlook, the conversion of forests to annual crops. These interactions reiterate the importance attributed by Nemecek et al. (2011) and MullerLindenlauf et al. (2010) of considering the whole system and multiple impact categories, in assessing environmental performances of producing beef.

However, Nguyen et al. (2010) proposed that this value would increase about 3.1-3.9 times with the consideration of land use aspects. In our work, this effect could be simulated by assuming that the IS has been obtained from improvements applied in ES. As a consequence, the total GHG emissions in the IS would be $1.38 \mathrm{~kg}$ $\mathrm{CO}_{2}$ eq $/ \mathrm{kg}$ LWG instead of $9.16 \mathrm{~kg} \mathrm{CO}$ eq/kg LWG. Flysjo et al. (2012) observed the importance of reporting the emissions from the land use change separately because this emissions source can drastically affect the GHG emissions.

\subsection{Resource depletions}

With a similar order to that found in the present study (95 and 217 l/kg LWG), the analysis of six systems for meat production in New South Wales, Australia, by Ridoutt et al. (2012) revealed different values of water consumption (3.3-221 l/kg LWG). Thus, these authors state that the meat production in the pasture has no significant impact on water use, suggesting that the supposed contribution of livestock production to the water scarcity worldwide is unfounded.

In regard to metal depletion, the range of our results was boosted by the sharp contrast between the two systems. Fertilizers, limestone and mineral salt containing different metals and the introduction of grass and leguminous plants were used in the IS. Therefore, the only external input used in the ES was the common salt.

The effect of leguminous introduction was evident in the definition of fossil depletion, because the effect of $\mathrm{N}$ fixation annulled all of the contributions from other activities that are characteristic in the IS. Moreover, the choice of using leguminous plants instead of nitrogen fertilizers contributed to the reduction of GHG emissions, reiterating the claims of Yan et al. (2013), on their importance in animal production systems based on pastures and highlighting the multifactorial nature of the practice.

\subsection{Terrestrial acidification and freshwater eutrophication}

The effects of grazing and nutrient losses from pastures are reflected, as proposed by Peters et al. (2011), in indicators of terrestrial acidification observed in ES and IS systems, albeit differently. Although there is a less soil erosion in the IS due to the control of the animal's permanence in the paddocks and forage supply, there is decrease in soil cover and increased the potential losses of nutrients in the ES from the continuous selective grazing. The values obtained in this category ( 0.0028 and $0.0038 \mathrm{~kg} \mathrm{SO}_{2} \mathrm{eq} / \mathrm{kg} \mathrm{LWG}$ for the ES and the IS, respectively) are different to the values found by Ogino et al. (2007) in Japan (0.248 $\mathrm{kg} \mathrm{SO}$ eq/ $\mathrm{kg}$ LWG), and by Nguyen et al. (2010) in the $\mathrm{EU}\left(210 \mathrm{~g} \mathrm{SO}_{2} \mathrm{eq} / \mathrm{kg} \mathrm{HSCW}\right.$, which corresponds to approximately $0.1 \mathrm{~kg} \mathrm{SO}$ eq/kg LWG). The appreciation of these relationships should consider the greater degree of intensity of the systems studied by these authors.

This statement is reinforced by the observed difference between the amount of freshwater eutrophication obtained in this study $(0.00383$ and $0.00219 \mathrm{~kg} \mathrm{P}$ eq/ $/ \mathrm{kg}$ LWG, for the ES and the IS, respectively) and the values proposed by Ogino et al. (2007) for Japanese production systems ( $0.0431 \mathrm{~kg} P$ eq/ $/ \mathrm{kg}$ LWG).

The values obtained in both categories (terrestrial acidification and freshwater eutrophication) are dependent on the local soil and climatic conditions, as well as other characteristics inherent to production systems, which, according to De Vries and De Boer (2010), prevent the determination of standards and makes comparisons between systems difficulties. For example, Ogino et al. (2004) showed that animal manure emissions are the main source of acidification and eutrophication; in contrast, the contribution of manure was less important in our study. Castanheira et al. (2010) suggested that the largest source of emissions to air and water from cattle production systems is the production of concentrates, which is not even analyzed in this work.

\section{Conclusions}

The potential environment impacts of $1 \mathrm{~kg}$ live weigh gain (LWG) produced in two typical beef cattle production systems of 
southern Brazil, the extensive and the improved systems were shown to differ considerably. Productive improvements were related in IS to environmental benefits in terms of global warming, land use, freshwater eutrophication and depletion, and fossil depletion, when expressed per unit of product. However, minor external input use results in advantages in terms of terrestrial acidification and metal depletion for ES. These differences and apparent dualities reiterate the importance of considering the whole system and multiple impact categories, in assessing environmental consequences of producing beef.

Different features of both systems contribute to these impacts. The permanence time of the animals and the quality and production of the pastures determine the GHG emissions, land use, and freshwater depletion, whereas the pasture improvement practices and salt supply to the animals define the metal depletion and terrestrial acidification. Similarly, the freshwater eutrophication is directly related to the loss of nutrients from the pasture by runoff and leaching, whereas the introduction of leguminous plants was found to be decisive regarding fossil depletion.

Strategies in order to mitigate the environmental potential impacts of beef cattle production should focus on productive upgrading. Improvement of pasture management with local ingredients should be favored in the ES. In the IS the environmental performance of beef production could be increased by introducing high production tropical forage species and more intensive rotational grazing. Increasing beef production levels and reducing methane production from enteric fermentation and land use could represent critical pathways towards more environmentally friendly cattle production in two systems, despite their differences. However, these changes should be addressed by LCA studies, in order to assure that the switch to an alternative practice does not create other problems.

To the best of our knowledge, this work represents the first LCA of beef cattle production in Brazil that accounts for all environmental impacts during the productive life of different animal categories that comprise the main systems. This work is intended to contribute to a greater understanding of beef production in the context of sustainability and provides a new perspective in which the livestock industry seeks improvements not only in its productivity but also in its social and environmental characteristics.

\section{Acknowledgments}

The financial support of CAPES (Coordination for Enhancement of Higher Education Personnel) is gratefully acknowledged.

\section{References}

Arsenault, N., Tyedmers, P., Fredeen, A., 2009. Comparing the environmental impacts of pasture-based and confinement-based dairy systems in Nova Scotia (Canada) using life cycle assessment. Int. J. Agric. Sustain. 7 (1), 19-41.

Bartl, K. Gómez, C.A., Nemecek, T, 2011. Life cycle assessment of milk produced in two smallholder dairy systems in the highlands and the coast of Peru. J. Clean. Prod. 19 (13), 1494-1505.

Beauchemin, K.A., Janzen, H.H., Little, S.M., McAllister, T.A., McGinn, S.M., 2010. Life cycle assessment of greenhouse gas emissions from beef production in western Canada: a case study. Agric. Syst. 103 (6), 371-379.

Beauchemin, K.A., Janzen, H.H., Little, S.M., McAllister, T.A., McGinn, S.M., 2011 Mitigation of greenhouse gas emissions from beef production in western Canada - evaluation using farm-based life cycle assessment. Anim. Feed Sci. Technol. 166-167, 663-677.

Blanco, C., Sosinski, E., Santos, B., Abreu da Silva, M., Pillar, V.P., 2007. On the overlap between effect and response plant functional types linked to grazing. Commun. Ecol. 8 (1), 57-65.

Capper, J.L., Cady, R.A., Bauman, D.E., 2009a. Increased production reduces the dairy Industry's environmental impact. In: Proceedings of the 18th Annual Tri-state Dairy Nutrition Conference, pp. 71-82.

Capper, J.L., Cady, R.A., Bauman, D.E., 2009b. The environmental impact of dairy production: 1944 compared with 2007. J. Anim. Sci. United States, 2160-2167.
Casey, J.W., Holden, N.M., 2006. Quantification of GHG emissions from sucker-beef production in Ireland. Agric. Syst. 90 (1-3), 79-98.

Castanheira, É.G., Dias, A.C., Arroja, L., Amaro, R., 2010. The environmental performance of milk production on a typical Portuguese dairy farm. Agric. Syst. 103 (7), 498-507.

Cederberg, C., Meyer, D., Flysjö, A., 2009. Life Cycle Inventory of Greenhouse Gas Emissions and Use of Land and Energy in Brazilian Beef Production. SIK-report. SIK - Institutet för livsmedel och bioteknik.

Consoli, F., 1993. Guidelines for Life-cycle Assessment: a Code of Practice. Society of Environmental Toxicology and Chemistry, (SETAC).

Corrêa, E.S., 2001. Desempenho reprodutivo em um sistema de produção de gado de corte. Embrapa Gado de Corte.

De Vries, M., De Boer, I.J.M., 2010. Comparing environmental impacts for livestock products: a review of life cycle assessments. Livest. Sci. 128 (1-3), 1-11.

Dollé, J.B., Agabriel, J., Peyraud, J.L., Faverdin, P., Manneville, V., Raison, C., Gac, A., Le Gall, A., 2011. Les gaz à effet de serre en élevage bovin: évaluation et leviers d'action. Prod. Anim. 24 (5), 415

Elferink, E.V., Nonhebel, S., 2007. Variations in land requirements for meat production. J. Clean. Prod. 15 (18), 1778-1786.

Euclides Filho, K., 2000. Produção de bovinos de corte eo trinômio genótipoambiente-mercado. Embrapa Gado de Corte.

Flysjo, A., Cederberg, C., Henriksson, M., Ledgard, S., 2012. The interaction between milk and beef production and emissions from land use change - critical considerations in life cycle assessment and carbon footprint studies of milk. J. Clean. Prod. 28, 134-142.

Frischknecht, R., Tuchschmid, M., Faist Emmenegger, M., Bauer, C., Dones, R., 2007. Strommix und Stromnetz. ecoinvent report No. 6 data v2.0. In: Dones, R. (Ed.), Sachbilanzen von Energiesystemen: Grundlagen für den ökologischen Vergleich von Energiesystemen und den Eunbezug von Energiesystemen in Ökobilanzen für die Schweiz. Paul Scherrer Institut Villigen, Swiss Centre for Life Cycle Inventories, Duebendorf, $\mathrm{CH}$.

Goedkoop, M., Heijungs, R., Huijbregts, M., Schryver, A.D., Struijs, J., Van Zelm, R., 2009. ReCiPe 2008: a Life Cycle Impact Assessment Method Which Comprises Harmonised Category Indicators at the Midpoint and the Endpoint Level. In: VROM-Ruimte en Milieu, Ministerie van Volkshuisvesting, Ruimtelijke Ordening en Milieubeheer.

Goedkoop, M., Schryver, A.D., Oele, M., Durksz, S., de Roest, D., 2010. Introduction to LCA with SimaPro 7. Pré Consultants.

Gonzalez, H.L., Velho, I.M.P.H., Abreu da Silva, M., Medeiros, R.B., Paim, N.R., Nörnberg, J.L., 2009. Milk quality of Jersey cows kept on winter pasture supplemented or not with concentrate. Braz. J. Anim. Sci. 38 (10), 1983-1988.

Haas, G., Wetterich, F., Kopke, U., 2001. Comparing intensive, extensified and organic grassland farming in Southern Germany by process life cycle assessment. Agric. Ecosyst. Environ. 83 (1-2), 43-53.

Halberg, N., Van der Werf, H., Basset-Mens, C., Dalgaard, R., de Boer, I., 2005. Environmental assessment tools for the evaluation and improvement of European livestock production systems. Livest. Prod. Sci. 96 (1), 33-50.

IBGE, 2011. Produção da Pecuária Municipal, Rio de Janeiro, p. 65.

IBGE, 2012. Censo Agropecuário 2006. Grandes Regiões e Unidades da Federação, Brasil, p. 778. Rio de Janeiro.

IPCC, 2006a. IPCC Guidelines for National Greenhouse Gas Inventories, Agriculture, Forestry and Other Land Use. In: $\mathrm{N}_{2} \mathrm{O}$ Emissions from Managed Soils, and $\mathrm{CO}_{2}$ Emissions from Lime and Urea Application, p. 54.

IPCC, 2006b. IPCC Guidelines for National Greenhouse Gas Inventories, Agriculture, Forestry and Other Land Use. In: Emissions from Livestock and Manure Management, p. 89.

ISO14040, 2006. 14040 Environmental Management-life Cycle Assessmentprinciples and Framework. International Organization for Standardization, London.

ISO14044, 2006. 14044: Environmental Management-life Cycle Assessment-requirements and Guidelines. International Organization for Standardization.

Jungbluth, N., Chudacoff, M., Dauriat, A., Dinkel, F., Doka, G., Faist Emmenegger, M., Gnansounou, E., Kljun, N., Schleiss, K., Spielmann, M., Stettler, C., Sutter, J., 2007. Life Cycle Inventories of Bioenergy. ecoinvent report No. 17. Swiss Centre for LCI, Dübendorf, $\mathrm{CH}$.

Kichel, A.N., Costa, J.A.A., Verzignassi, J.R., Queiroz, H.P., 2011. Diagnóstico para o planejamento da propriedade. Embrapa Gado de Corte, p. 182.

Krolow, R.H. Abreu da Silva, M., Paim, N.R., Medeiros, R.B., Gonzalez, H.L. 2012. Milk composition of Holstein cows grazing ryegrass with the use of white clover as a protein source. Braz. J. Veterinary Anim. Sci. 64 (5), 1352-1359.

Lalman, D., Doye, D., 2005. Beef Cattle Manual. Oklahoma State University.

Lima, A.L., Pessoa, M., Ligo, M.A.V., 2002. Primeiro inventário brasileiro de emissões antrópicas de gases de efeito estufa: Relatórios de referência-Emissões de metano da pecuária. IBGE-EMBRAPA-MCT, Brasília.

Maraschin, G.E., 2001. Production potential of South America grasslands. In: Proceedings of the XIX International Grassland Congress: Grassland Ecosystems: an Outlook into the 21st Century, pp. 5-15.

Mc Geough, E.J., Little, S.M., Janzen, H.H., McAllister, T.A., McGinn, S.M., Beauchemin, K.A., 2012. Life-cycle assessment of greenhouse gas emissions from dairy production in Eastern Canada: a case study. J. Dairy Sci. 95 (9), $5164-$ 5175 .

Medeiros, R.B., Pedroso, C.E.S., Jornada, J.B.J., Abreu da Silva, M., Saibro, J.C., 2007. Diurnal ingestive behavior of sheep grazing annual ryegrass at different phenological growth stages. Braz. J. Anim. Sci. 36 (1), 198-204. 
Muller-Lindenlauf, M., Deittert, C., Kopke, U., 2010. Assessment of environmental effects, animal welfare and milk quality among organic dairy farms. Livest. Sci. $128(1-3), 140-148$

Nemecek, T., Huguenin-Elie, O., Dubois, D., Gaillard, G., Schaller, B., Chervet, A., 2011. Life cycle assessment of Swiss farming systems: II. Extensive and intensive production. Agric. Syst. 104 (3), 233-245.

Nemecek, T., Kägi, T., 2007. Life Cycle Inventories of Agricultural Production Systems. Final report ecoinvent V2.0 No. 15. Agroscope Reckenholz-Taenikon Research Station ART, Swiss Centre for Life Cycle Inventories, Zurich and Düberdorf, $\mathrm{CH}$.

Nguyen, T.L.T., Hermansen, J.E., Mogensen, L., 2010. Environmental consequences of different beef production systems in the EU. J. Clean. Prod. 18 (8), 756-766.

NRC, 2000. Nutrient Requirements of Beef Cattle E-974. Department of Animal Science, Oklahoma.

Nunes, I.J., 1998. Nutrição animal básica, second ed. FCP-MVZ ED, Belo Horizonte.

Ogino, A., Kaku, K. Osada, T. Shimada, K., 2004. Environmental impacts of the Japanese beef-fattening system with different feeding lengths as evaluated by a life-cycle assessment method. J. Anim. Sci. 82 (7), 2115-2122.

Ogino, A., Orito, H., Shimada, K., Hirooka, H., 2007. Evaluating environmental impacts of the Japanese beef cow - calf system by the life cycle assessment method. Anim. Sci. J. 78 (4), 424-432.

Oliveira, R.L., Barbosa, M.A.A.F., Ladeira, M.M., Silva, M.M.P., Ziviani, A.C., Bagaldo, A.R., 2006. Beef cattle nutrition and production during reproduction phase. Braz. J. Anim. Health Prod. 7 (1), 57-86.

Pedroso, C.E.S., Medeiros, R.B., Abreu da Silva, M., Jornada, J.B.J., Saibro, J.C., Teixeira, J.R.F., 2004. Sheep behavior at the pregnancy and at the lactation grazing on different phenological stages of annual ryegrass. Braz. J. Anim. Sci. 33 (3), 1340-1344.

Peters, G.M., Wiedemann, S., Rowley, H.V., Tucker, R., Feitz, A.J., Schulz, M., 2011. Assessing agricultural soil acidification and nutrient management in life cycle assessment. Int. J. Life Cycle Assess. 16 (5), 431-441.

Pillar, V., Tornquist, C.G., Bayer, C., 2012. The Southern Brazilian grassland biome: soil carbon stocks, fluxes of greenhouse gases and some options for mitigation. Braz. J. Biol. 72, 673-681.
Rattray, P.V., 2005. Clover management, Research, Development and Extension in the New Zealand Pastoral Industries. Commissioned by the Sustainable Farming Fund, p. 218.

Ridoutt, B.G., Sanguansri, P., Freer, M., Harper, G.S., 2012. Water footprint of livestock: comparison of six geographically defined beef production systems. Int. J. Life Cycle Assess. 17 (2), 165-175.

Robèrt, K.H., 2000. Tools and concepts for sustainable development, how do they relate to a general framework for sustainable development, and to each other? J. Clean. Prod. 8 (3), 243-254.

Ruviaro, C.F., Gianezini, M., Brandão, F.S., Winck, C.A., Dewes, H., 2012. Life cycle assessment in Brazilian agriculture facing worldwide trends. J. Clean. Prod. 28 (0), 9-24.

Santos, B.R.C., Abreu da Silva, M., Medeiros, R.B., 2006. Interaction between grazing behavior and functional type dynamics in native grassland in the centra depression region of Rio Grande do Sul. Braz. J. Anim. Sci. 35 (5), 1897-1906.

Scholl, J.M., Lobato, J.F.P. Barreto, I.L., 1976. Improvement of pastures by direct seeding into native grass in Southern Brazil with oats and with nitrogen supplied by fertilize or arrow leaf clover. Turrialba 26 (2), 144-149.

Siqueira, O.J.F., Scherer, E.E., Tassinari, G., Anghinoni, I., Patella, J.F., Tedesco, M.J., Milan, P.A., Ernani, P.R., 1987. Recomendações de adubação e calagem para os estados do Rio Grande do Sul e Santa Catarina. EMBRAPA-CNPT.

Stackhouse-Lawson, K.R., Rotz, C.A., Oltjen, J.W., Mitloehner, F.M., 2012. Carbon footprint and ammonia emissions of California beef production systems. J. Anim. Sci. 90 (12), 4641-4655.

Teixeira, J.R.F., Abreu da Silva, M., 2007. Typology of beef cattle production systems related to ectoparasitosis frequency. Braz. J. Anim. Sci. 36 (6), 2176-2183.

Weiss, F., Leip, A., 2012. Greenhouse gas emissions from the EU livestock sector: a life cycle assessment carried out with the CAPRI model. Agric. Ecosyst. Environ. 149 (0), 124-134.

Yan, M.J., Humphreys, J. Holden, N.M., 2013. The carbon footprint of pasturebased milk production: can white clover make a difference? J. Dairy Sci. 96 (2), 857-865. 